\title{
Some Great Moments in the Practice of Forestry in Québec (1910-2020)
}

\author{
by Pierre Mathieu, ing.f. (retired), MGP'1
}

[The following text is based on a document presented in French by the author during the Virtual Annual Meeting of the Canadian Institute of Forestry September 17, 2020. It was previously published in French in the magazine Histoires forestières du Québec, 12(1) https://shfq.ca/wp-content/uploads/2020/10/revue-automne2020-BR-1.pdf_

The translation was done by Jean-Claude Mercier, president of the Société d'histoire forestière du Québec (QFHS). Pierre Mathieu is an administrator of the QFHS. Contact: Gerard Lacasse, director general, direction@histoiresforestieres.com SHFQ, Pavillon Abitibi-Price, local 2101, 2405 rue de la Terrasse, Quebec, Qc, G1V0A6]

\section{ABSTRACT}

In 1910, the Forestry School at Laval University was founded at the instigation of the Government of Quebec so that research provides the knowledge needed to intelligently manage the Crown lands. The two and sole teachers at this school were Gustave-Clodomir Piché and Avila Bédard. These first two Quebec forest engineers would develop many forest programs and organizations in Quebec at a time when everything had to be built. It has therefore been a little over 110 years that we have been teaching and practising scientific forestry in Quebec. Scientific knowledge, cultural values, social context, various forest regimes not to mention the many forestry crises have contributed to the evolution of forestry practices.

Keywords: Coulombe Commission, Gustave-Clodomir Piché, Avila Bédard, Le problème forestier du Québec, Forêt Montmorency, Ordre des ingénieurs forestiers du Québec (OIFQ), Dignity Operations (Opérations dignité)

\section{RÉSUMÉ}

En 1910, l'École forestière de l'Université Laval a été fondée par la volonté du gouvernement du Québec afin que la recherche procure les connaissances pour gérer intelligemment les terres de la Couronne. Les deux seuls et premiers professeurs de cette école étaient Gustave-Clodomir Piché et Avila Bédard. Ces deux premiers ingénieurs forestiers québécois furent les instigateurs de nombreux programmes et organismes forestiers au Québec à l'époque où tout était à bâtir. Cela fait donc un peu plus de 110 ans que l'on enseigne et pratique la foresterie scientifique au Québec. Les connaissances scientifiques, les valeurs culturelles, le contexte social, les divers régimes forestiers sans oublier les nombreuses crises forestières ont contribué à l'évolution des pratiques forestières.

Mots clés: Coulombe Commission, Gustave-Clodomir Piché, Avila Bédard, Le problème forestier du Québec, Forêt Montmorency, Ordre des ingénieurs forestiers du Québec (OIFQ), Dignity Operations (Opérations dignité)

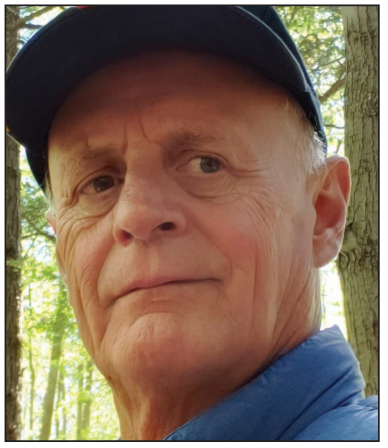

Pierre Mathieu

\section{Outlook}

In 1910, the Forestry School at Laval University was founded at the instigation of the Government of Quebec so that research provides the knowledge needed to intelligently manage the Crown lands. The two and sole teachers at this school were GustaveClodomir Piché and Avila Bédard. These first two Quebec forest engineers would develop many forest programs and organizations in Quebec at a time when everything had to be built. It has therefore been a little over 110 years that we have been teaching and practising scientific forestry in Que- bec (Gélinas 2010; Ordre des ingenieurs forestiers du Québec 2003). For its part, the Association of Forest Engineers was created in 1921. Now known as the Order of Forest Engineers of Quebec (OIFQ), this organization celebrates its $100^{\text {th }}$ anniversary this year (Ordre des ingenieurs forestiers du Québec 1996b).

Of course, forestry has undergone constant change over the past 110 years. Scientific knowledge, cultural values, social context, various forest regimes not to mention the many forestry crises have contributed to the evolution of forestry practices. And it goes without saying, the forest itself has aged and has been modulated, sometimes by fire, disease or human intervention (Paillé 2012; Mercier 2017).

\section{The beginning of scientific forestry (1910-1949)}

Forest management started out as a business of people of goodwill. A North American forestry congress, held in

1email: anticosti3@gmail.com 


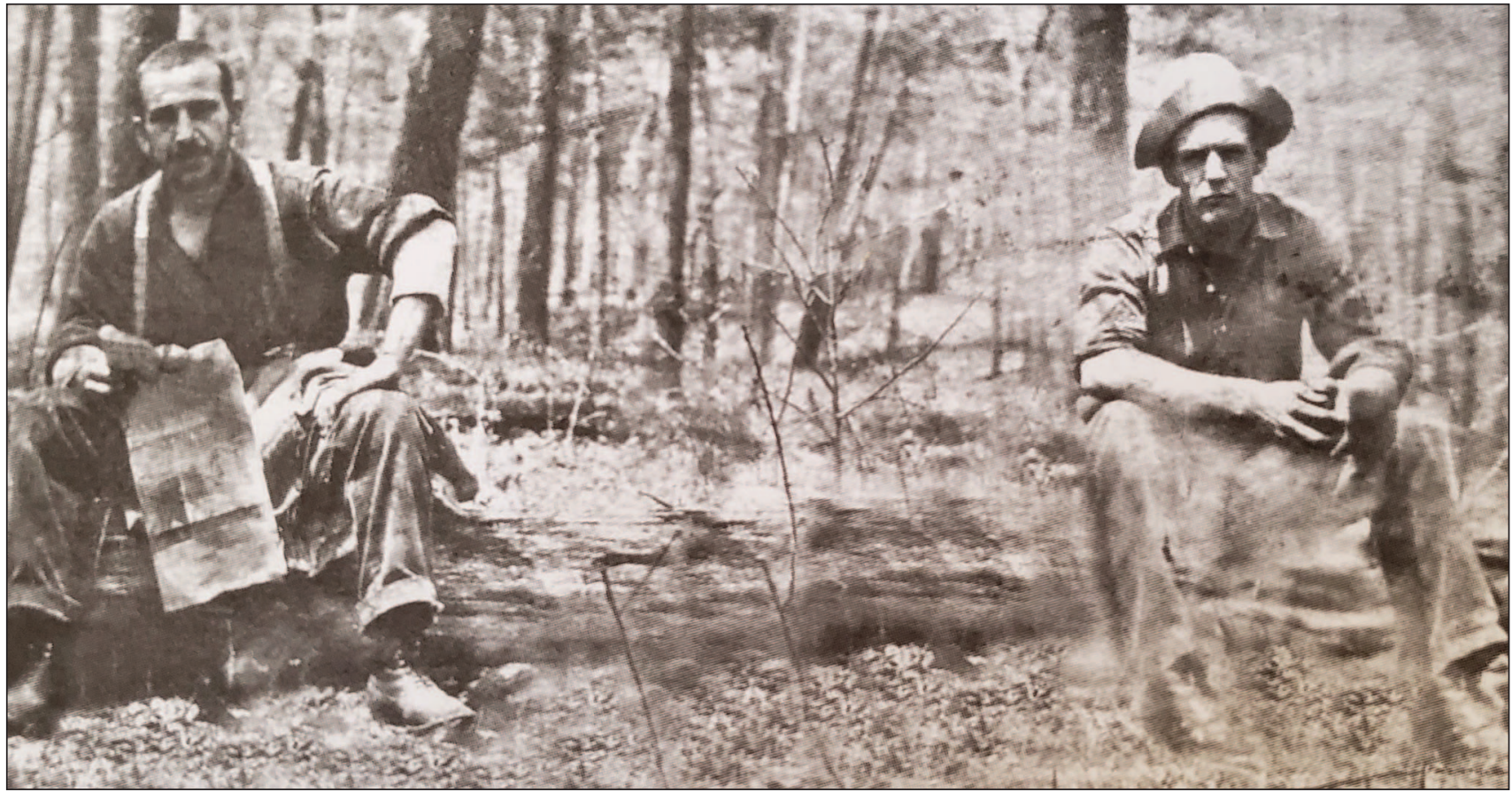

Gustave-Clodomir Piché and Avila Bédard at Yale, in 1906; (SHFQ, private collection of the Piché family)

Montreal in 1882, helped raise awareness among a few people whose activities or interests laid closer to the forestry community.

At the end of the $19^{\text {th }}$ century, the accelerated development of the pulp and paper industry made it essential to establish healthier forestry practices. It was also a time of conflict between settlement and industrial forestry on Crown lands and "war" against forest fires (Blanchet 2003). Note that yesterday's enemy is today a source of inspiration for planning strategies which are largely inspired by natural disturbances.

It is in this context that the liberal government of Omer Gouin granted in 1905 a scholarship to Gustave-Clodomir Piché and Avila Bédard in order to allow them to complete a two-year training in the United States at the Yale University's Forestry School in New Heaven. Graduates as "Master in Forestry", they multiplied initiatives both within government and the domain of education. Piché and Bédard are considered the fathers of scientific forestry in Quebec (Blanchet 2010).

Head of the forest service in 1908, Piché was at the center of several initiatives including soil classification, the first nursery in Berthierville, the first forest inventories, he founded and was the first director of the Forestry School at Laval University in 1910, and contributed to the establishment of the Association of Forest Engineers of Quebec with Omer Lussier, who was its first president (1921).

On the industrial side, Ellwood Wilson, an American, was one of the first professional foresters hired in 1907 by a paper company in Canada, the Laurentide Company Limited in Mauricie (Quebec) (Alvarez 2020a). There he was a pioneer in the use of aerial photography, land use planning, allowable cut calculations, reforestation, nurseries and genetics. His influence extended far beyond the framework of his own company (Alvarez 2020a). For many years, the Anglo-Saxon owned forest industry did not hire forest engineers trained at Laval University. This situation persisted for a long time.

The first global reflections on forest inventories, silvicultural practices and forest administration began at the end of the 1930s under the leadership of Omer Lussier. He founded the Association forestière québécoise in 1939, a popular education movement devoted to forest conservation. Among others, Piché and Bédard continued their efforts, often using the Quebec Forest Association, and its publications to promote the scientific approach to forestry.

In 1949, the Corporation of Forest Engineers, which had succeeded the Association of Forest Engineers of Quebec, published Le problème forestier du Québec (The Forest Problem of Quebec), an update of its 1938 forest policy and action program. This masterful work addressed all aspects of forestry. Unfortunately, it received little government attention and its impact will be limited.

\section{The development of a global vision of forest policy (1949-1973)}

The 60 s, what a time! We are in the middle of a quiet revolution with the coming to power of Premier Jean Lesage's "team of thunder". Everything is called into question in Quebec after what has been called "the dark years" under the reign of Maurice Duplessis (Gossage and Little 2015). The forestry sector is no exception. In 1961, the Ministry of Lands and Forests succeeded the Department of the same name. A new forest policy is in sight.

The Corporation of Forest Engineers of Quebec responded to a call from Minister Bona Arsenault to update The Forest Problem of Quebec, published in 1949.

The 1962 version is a hundred pages long and has many recommendations (Corporation des ingénieurs forestiers de 


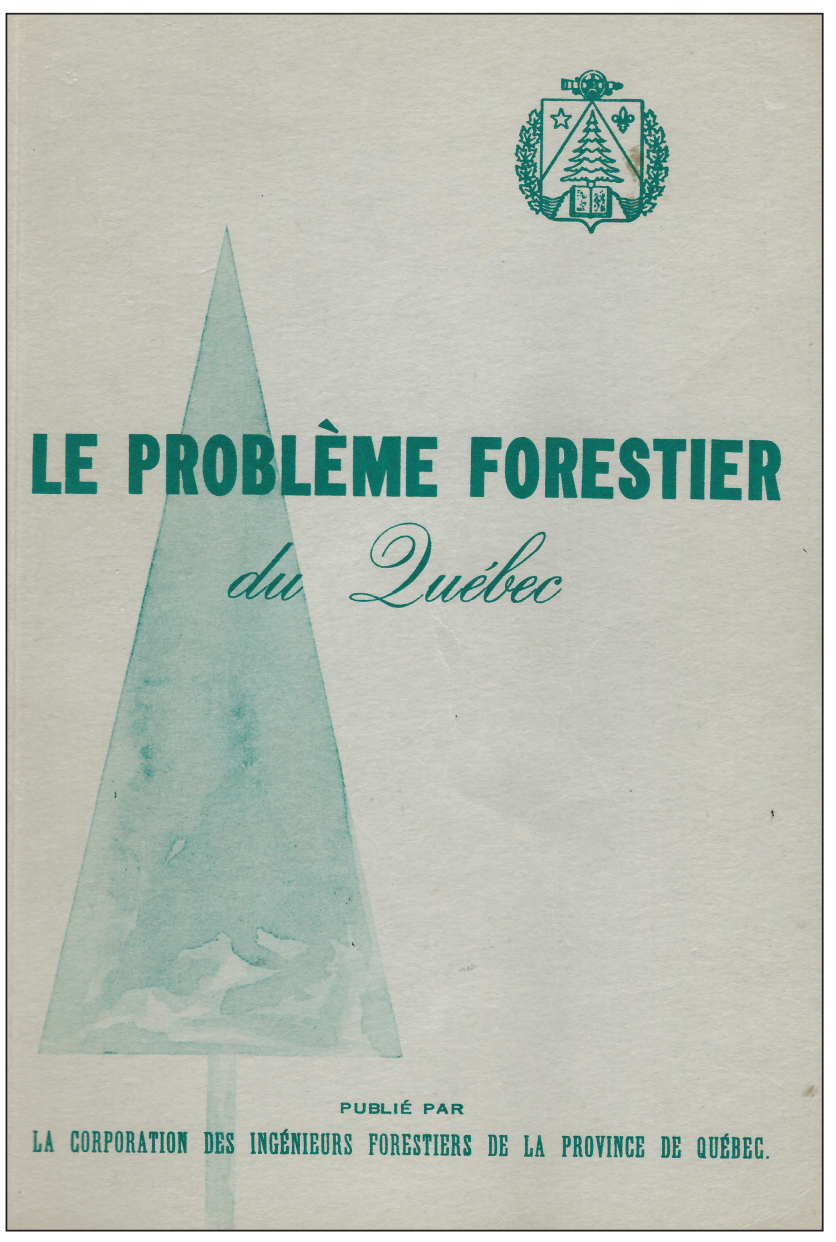

Le problème forestier du Québec (The Forest Problem of Quebec), 1962

la province du Québec 1962). It met with a better reception. It covered all facets of forestry, both in terms of science and industrial development. The brief and its recommendations impacted significantly on many forest practices and policies such as inventory, reforestation, silviculture, education at the secondary, college and university levels, research, logging, labour and the social role of the forest. There was so much to do, so much to build. Was this the beginning of a golden age for forest engineers?

This brief marked the real beginning of an impressive series of opinions and briefs that forest engineers wrote in subsequent years (Ordre des ingénieurs forestiers du Québec 1996a, 2008).

An interesting recommendation of The Forest Problem of Quebec has never been implemented. It was proposed to present the forest land and timber as a capital and, based on a perpetual inventory, account for its annual changes in volume and value.

\section{Private practice at the heart of innovations in forest inventory}

Since the completion of the first forest inventories in the mid-1920s, including those carried out by forest engineer Marie-Albert Bourget, consulting engineering companies have greatly contributed to the improvement of forestry practices in Quebec. Forestry consultants have been at the heart of innovations in forest inventory and photo-interpretation, particularly with the arrival of GPS, geographic information system (GIS) software on PC-type computers and satellite imagery. The consultants have been able to continuously adapt to different forest policies, notably the abolition of forest concessions in the 1970s which changed the role of their industrial clientele (Société d'histoire forestière du Québec 2017).

In addition, consulting engineering companies had great success at the international level (Africa and Latin America) in the 80s and 90s (Kérouac 2017). At the end of the $20^{\text {th }}$ century, $10 \%$ of forest engineers in Quebec were working or had worked in international forestry. One of them, the forest engineer Jean-Louis Kérouac was the secretary general of the World Forestry Congress held with great success in Quebec in 2003 .

\section{The private forest serves the recognition of forest engineers well (1960)}

Although harvesting timber in private forests goes way back to early colonization, it was not until 1940 that the Province assigned the first forest engineers to private forests by creating the Bureau des renseignements forestiers (Forest Extension Office). Over the years, the collective and individual assistance programs put in place by Quebec and the federal governments have enabled forest engineers to provide their professional services and gain recognition from many woodlot owners. Over time, and more than once, the standards that define professional practice in private forests have come to the fore. In 1980, renowned forest engineer Marcel Lortie conducted a consultation on this subject, which was also discussed in depth at the Private Forest Summit in 1995.

The forestry cooperatives, born at the end of the 1930s, who served mostly as logging subcontractors in forestry operations for concessions owners, have been able to use the expertise of forestry engineers throughout the evolution of their business model. The 1976 report by forest engineers Gilbert Paillé and André McNeil on the future of forest cooperatives brought a breath of fresh air to a movement that was then in dire straits in the wake of the abolition of forest concessions.

The link between private forest and public forest has always been a subject of interest for forest engineers. They shared their opinions about land use planning through community development (1976), the concept of the inhabited forest (1997) and community forests (2011).

\section{The Montmorency Forest, the largest educational forest (1964)}

Located a one-hour drive from Laval University, the Forêt Montmorency (Montmorency Forest) is the site of more than 50 years of research and experimentation. This forest is an important place of training for teachers and students. It is now the largest teaching and research forest in the world $\left(397 \mathrm{~km}^{2}\right)$ and a popular recreation area. Since 1964, through successive forest management plans, the sustainable production of wood was progressively increased in full respect for other uses of forest resources and the conservation of biodiversity. 
This has to be attributed in part to the visionary forest engineers who built the Montmorency Forest, including: Edgar Porter, Roger Gosselin, André Lafond and Robert Bellefeuille.

\section{Focus on public protection (1973)}

The entry into force of the Professional Code (Code des professions) in 1973 marked a major turning point for the 38 professional corporations. It stems from the legislator's concern to protect the public in matters of professional services. The Professional Code deals with professional orders and rules on the vast majority of their powers and duties. Procedures related to ethics, professional inspection, discipline, syndic and continuing education are gradually being standardized for all professions. The implementation of these procedures by the Ordre des ingénieurs forestiers du Québec (OIFQ) leaves fewer resources available for the promotion and defence of the profession. Professional expertise in the Quebec forest sector is maintained and provided by forest engineers. The forest engineer occupies an exclusive field of practice defined in the Forest Engineers Act.

\section{Opening up to regional planning (1975)}

In the early 1970s, the Dignity Operations (Opérations dignité) rallied the population of Bas-Saint-Laurent and the Gaspé Peninsula who opposed the government's plan to close so-called marginal parishes and bring people closer to the labour market. Yielding to popular pressure, the government opted for a different approach. A proposal presented in 1976 by the OIFQ on land use planning through community development was well received and influenced the new approach to develop the agroforestry potential of the region. The territory of those two regions was divided in thirteen planning units each under a Joint Management Organization (CMO). Four of these were called Forestry Groups (Regroupements forestiers) and nine others named Resource Exploitation Societies (Sociétés d'exploitation des ressources).

In 1975, under the leadership of its president Yvon Dubé, the OIFQ developed a comprehensive integrated approach to the management of all forest resources regrouped under a single government forestry authority. This approach was not adopted by the government at that time.

Further briefs and opinions of the OIFQ on the integrated development of all the resources of Quebec's parks, including wildlife, received better attention from the government in the period 1978 to 1982 .

\section{Participation in the Canadian Federation of Forest Engineers Associations (1982) and in multilateral collaboration}

From the founding of the Canadian Federation of Forest Engineers Associations in 1982, the Ordre des ingénieurs forestiers du Québec fully participated in the regrouping of the five associations of forest engineers in Canada and in the constitution of the Canadian Accreditation Board set up in 1987. The latter coordinates a national accreditation system for forestry study programs at seven Canadian universities. In terms of multilateral collaboration, the OIFQ and the Forestry Institute of Canada held a joint congress in Quebec in 2012. The Order also participated in 2013 in the FranceQuebec Forum on forests and wood utilization which further led to mutual professional recognition.

\section{Polarizing awakening to environmental concerns (1988)}

In the late 1980s, the debate over the use of pesticides in forestry, particularly to combat the spruce budworm epidemic, created a heated debate among forest engineers. Extensive consultation with members of the OIFQ indicated a circumstantial consensus in favour of maintaining the use of pesticides as part of an integrated management approach.

However, the use of pesticides in forests in Quebec was virtually abandoned after the adoption in 1994 of the Forest Protection Strategy which would ban the use of chemical pesticides in public forests as of 2001. Since then, forestry practices have been profoundly modified, particularly in the maintenance of plantations.

Hit hard by L'Erreur boréale (Boreal Error) [1999) Robert Monderie and singer Richard Desjardins presented a shocking documentary film "L'Erreur boréale”. In part due to the notoriety of the singer and film co-director Desjardins, this documentary was widely promoted and distributed. The sight and description of certain bad sides of forestry operations moved Quebecers in cities and regions alike. The forestry sector was hit hard. Since then, multiple efforts have been invested by forest engineers, government and the forest industry to correct the negative perception of the population that it is still being felt today (Alvarez 2020b).

In reaction, the majority of forestry consultants joined together to form the Association of Forestry Consultants in 2000. The new Association proposed to set up an audit system of forestry practices in Quebec covering works performed by employees of both public and private sectors. Their recommendation was not accepted.

The report of the Study Commission on the Management of Quebec's Public Forest (Coulombe Commission) in 2004 made more than 80 recommendations (Commission d'étude sur la gestion de la forêt publique québécoise 2004). Among

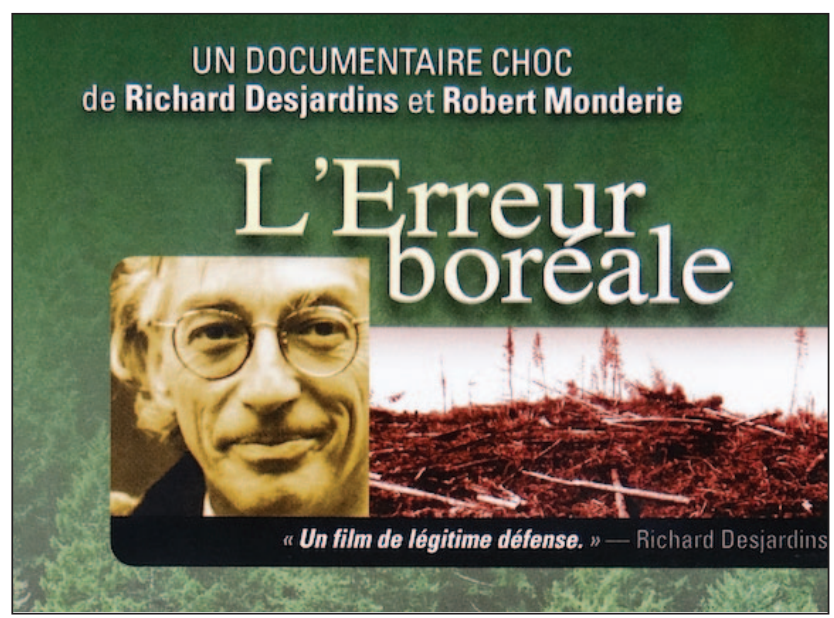

L'Erreur boréale (The Boreal Error) 


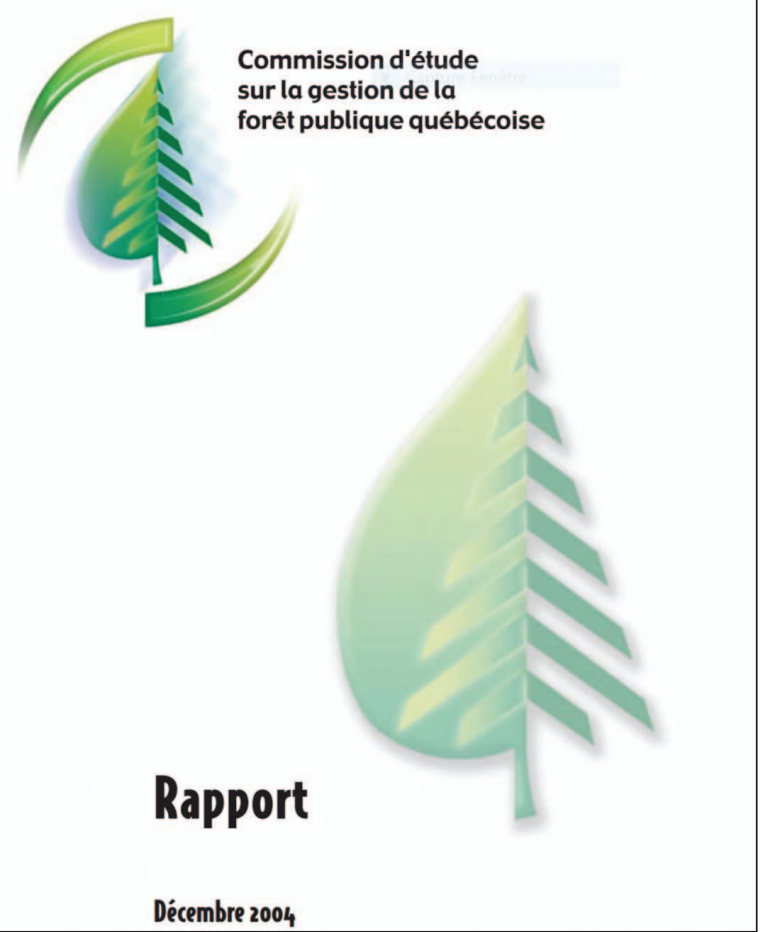

Commission d'étude sur la gestion de la forêt publique québécoise Rapport (Study Commission on the Management of Quebec's Public Forest Report]

those, the creation of a Chief Forester position and the reduction of wood harvesting by around $20 \%$ received much attention. Certain observations and recommendations in the report have reinforced the negative perceptions of forest management in Quebec.

The forestry sector suffered another upheaval when the Auditor General issued the opinion in her 2018 annual report that the responsible ministry could not state if the silvicultural investments of the past decades had yielded the desired results.

The general public's mistrust of the forestry sector is not new. The wide range of uses of the forest is conducive to the generation of clashes and conflicts that are often reported in the media. In particular one could note the difficult cohabitation of uses such as wood supply and the fully protected areas; the delimitation of wildlife sanctuaries and the organization of outfitting operations; the development of resort sites and the creation of parks.

In recent years, faced with a shortage of forest engineers possibly resulting from economic crises and negative perceptions, the OIFQ has to step up its strategy to promote the profession of forest engineer.

\section{Women foresters: $18 \%$ of the OIFQ, very active and in evidence}

Women have long been absent from the profession of forest engineer. Today, they represent $18 \%$ of the 1956 members of the OIFQ (as of March 31, 2019).
In 1956 Thérèse Sicard became the first forest engineer in Quebec and will remain the only one for more than twelve years (from 1956 to 1968) (Hébert 2011). From the mid1970s, the number of women in forestry grew up significantly. This period also corresponded to the evolution of forestry towards more environmental concerns. Is it a coincidence? More women are now occupying important forestry positions. Forest engineer Paule Têtu was Associate Deputy Minister responsible for public forests in Quebec from 2004 to 2008. Her tasks included the implementation of the Coulombe Commission recommendations. Johanne Gauthier was President and CEO of the OIFQ from 1998 to 2005. Worth mentioning is the long involvement of Yvette Jean who chaired the Professional Inspection Committee of the OIFQ for 28 years until 2019. More recently, forest engineer Nancy Gélinas became the first woman to become Dean of the Faculty of Forestry, Geography and Geomatics at Laval University.

\section{Towards a sustainable development of forest lands (2013)}

Forest management has evolved over the past 50 years. Originally focused exclusively on timber production from the 1950s to the 1970s, it moved to multiple use in the 1970s and finally to ecosystem management with the introduction of the Law on the Sustainable Development of Forest Land in 2013.

Since then, the government of Quebec assumed the planning of public forest management in Quebec, much like during the period 1975-1986, leaving little room for other actors in the forest sector and for the professional latitude of forest engineers. Some of this latitude was regained in 2018 when the OIFQ and the Ministry of Forests, Wildlife and Parks (MFFP) agreed to a procedure for the professional signing of forest engineers working at the MFFP.

\section{What's next?}

The next generation (2023-2028) of forest land management plans (integrated plans), will have to incorporate the legal objective of land use sustainability.

In 2015 a report on the economic aspect of the Sustainable Development Strategy for Forests, prepared by the former Dean of the Faculty of Forestry, Geomatics and Geography Robert Beauregard. It proposed a concept of wood production known as the "right to produce wood". The long-awaited response to this report was recently (2020) released by the government under the title Quebec Timber Production Strategy and its companion policy Wood integration in Construction. How will it fit in the new planning process?

Will the next major forest policy reform include the establishment of self-financed regional mixed (private-public) forest management companies? An eminent forest engineer Émile Ouellet liked to repeat that a forest regime must live at least twenty years. However, a place of reflection must be established and visionaries must get to work.

For 100 years, forest engineers have fully assumed their distinct character from engineers, with a different background that combines science and the social character of land occupation. The Faculty of Forestry, Geography and Geomatics at Laval University is the only educational institution in Quebec providing their training and has been doing so for 110 years. 


\section{References}

Alvarez, E. 2020a. Ellwood Wilson - pionnier de l'aménagement forestier. Histoires forestières du Québec 12(1) : 6-11.

Alvarez, E. 2020b. De la nécessité de s'affranchir de l'Erreur boréale. Forêts québécoises. $176 \mathrm{p}$.

Blanchet, P. 2003. Feux de forêt. L'histoire d'une guerre. Trait d'union. $184 \mathrm{p}$.

Blanchet, P. 2010. Les conflits d'usage et le début de la foresterie scientifique au Québec; 1867-1936. Le Naturaliste canadien 134 (1) : 62-69.

Commission d'étude sur la gestion de la forêt publique québécoise. 2004. Rapport. 307 p.

Corporation des ingénieurs forestiers de la province du Québec. 1962. Le problème forestier du Québec. $101 \mathrm{p}$.

Gélinas, C. 2010. L'enseignement et la recherche à l'Université Laval. Société d'histoire forestière du Québec. 231 p.

Gossage, P. et J.I. Little. 2015. Une histoire du Québec - Entre tradition et modernité. Cahiers du Québec. Éditions Hurtubise. 479 p. Hébert, M. 2011. Femmes forestières au Québec - regard anthropologique sur un univers professionnel. Société d'histoire forestière du Québec. 9 p.

Kérouac, J-L. 2017. L'origine et l'évolution du génie-conseil québécois sur les marchés internationaux. Histoires forestières du Québec. 9 (1) : 65-74.
Mercier, J-C. 2017. L'histoire forestière du Québec dans le contexte du $150^{\mathrm{e}}$ du Canada - de la Confédération à nos jours. Les colloques du Service canadien des forêts. PowerPoint.

Ordre des ingénieurs forestiers du Québec. 1996a. Portrait historique d'une profession - 75 ans d'expertise tournée vers l'avenir. $38 \mathrm{p}$. Ordre des ingénieurs forestiers du Québec. 1996b. Manuel de foresterie. Les Presses de l'Université Laval. 1428 p.

Ordre des ingénieurs forestiers du Québec. 2003. Dictionnaire de la foresterie - Dictionary of Forestry - Diccionario de foresteria. $744 \mathrm{p}$. Ordre des ingénieurs forestiers du Québec. 2008. Les ingénieurs forestiers, pour construire la forêt de demain. Mémoire déposé au Ministère des Ressources naturelles et de la Faune du Québec. 33 p. Paillé, G. 2012. Histoire forestière du Canada. Publications du Québec. $436 \mathrm{p}$.

Ryan, P. 2011. L'histoire d'un réseau à la défense des intérêts des coopératives forestières. Cahiers de l'ARUC - Développement territorial et coopération, Série "Recherches », no. 7. 110 p.

Société d'histoire forestière du Québec. 2017. Histoire de la pratique privée en foresterie depuis 1925. Histoires forestières du Québec. 9 (1). 86 p. 